
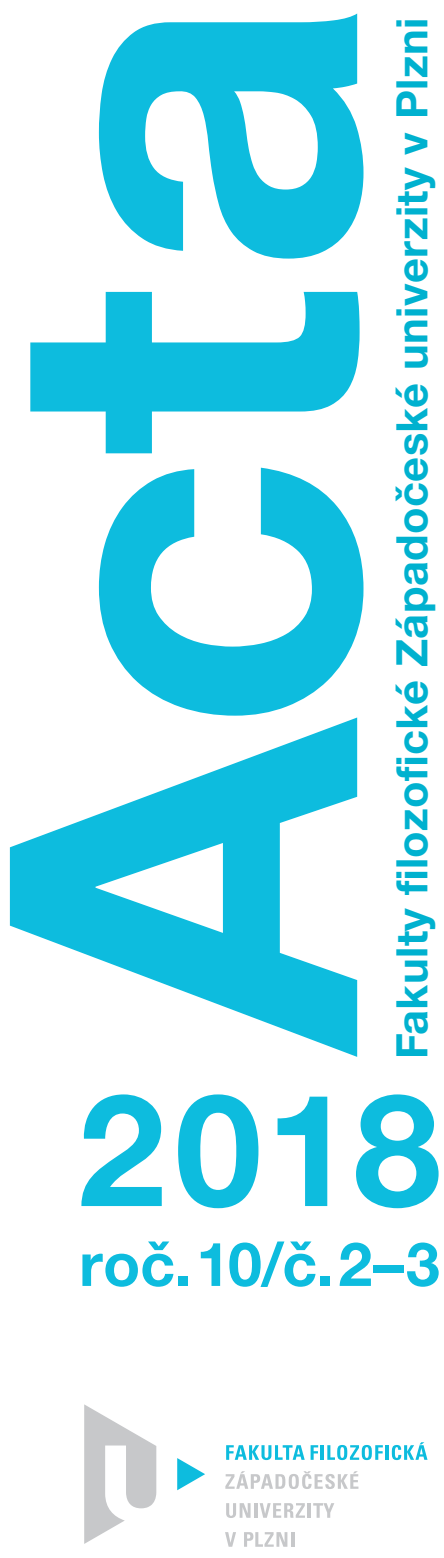


\title{
SaCred Romanesque ArChitecture Of KNIGHTS HOSPITALleR IN the POLISH LANDS
}

\author{
Paulina Gorazd-Dziuban*
}

\begin{abstract}
The Romanesque Knights Hospitaller's churches on the Polish Lands are only a fracture of the catalogue of the medieval architecture. Despite their small contribution to the history of the Church, they are extraordinary elements of the rich history of the Piast State. The paper will be based on historical studies on the history of the Order of Hospitallers; both in the Holy Land and, above all, in the Polish lands. The supplement will be research in the field of archeology concerning the main architecture, particular elements of which became the basis of developing the topic of Romanesque churches belonging to the Knights of St. John. The results of the research allow, to a large extent, to supplement and verify information about specific churches based on historical context. As a result, the presentation of the chosen churches mainly in Silesia and Pomerania will be based on the development of their original shape. These are used to present the development of endowment, their worship, ideological links and the functioning of the church as a temple in secular space. The presentation of the expansion of medieval culture of the Maltese Order allows a better understanding of their modest contribution to the development of Romanesque sacred constructions.
\end{abstract}

Key words: medieval architecture, Romanesque churches, hospitals, Knights Hospitallers, Templar Knights, Poland Kingdom, Silesia.

DOI: https://doi.org/10.24132/actaff.2018.10.2-3.2

*PM.A. Paulina Gorazd-Dziuban, Institute of Archaeology, Faculty of Sociology and History, University of Rzeszów, paulina.gorazd@gmail.com. 


\section{INTRODUCTION}

The history of Romanesque churches, including those of the Order of Saint John, located on Polish lands was the subject of research by historians and architects, but archaeological research has been carried out in two cases only. This article aims to highlight the problems of the temples belonging to the Knights Hospitaller, and to explain the foundations they obtained after the fall of the Knights Templar. The Churches owned by the monks of St. John were only a small part of the catalogue of medieval architecture in Poland. Despite this, they enrich the history of the Piast State and are the determinant of the idea which the donors were guided in the context of the development of their goods as well as spiritual enrichment. It was mainly this activity, associated with taking care looking after the pilgrims arriving in the Holy Land, which became the foundation for the charity of the fraternity, which, in time, would become a convent.

The history of Sovereign Military Hospitaller Order of Saint John of Jerusalem, of Rhodes and of Malta (Latin: Supremus Ordo Militaris Hospitalis Sancti Ioannis Hierosolymitani Rhodius et Melitensis) begins before the first crusade. Hereupon the Amalfi merchants, including Mauro di Pantaleona, purchased the area near the Holy Sepulcher from the caliphs of Jerusalem to built a hospice for pilgrims from Europe (Lange 1994: 15). Within Benedictine Abbey of Our Lady of Latin, a shelter was built for pilgrims and the poor of St. John the Baptist (Heś 2007: 26). Another name given to the hospital at which the organization was able to operate was patrocinium St. John the Dweller (Lange 1994: 15). The community was officially recognized by Pope Paschalis II in 1113. He established a fraternity at the hospital of St. John in Jerusalem, a religious congregation that was excluded from church structures, and which was the authority of the bishops either (Flavigny 2017: 13).

Brother Gerard, who, thanks to his organizational capacity, was the first source of power to leave a well-functioning community with its headquarters in Jerusalem, established the first European branch with fixed incomes (Heś 2007: 26-27). In Gerard's time, a white cross with the eight endings was trimmed on the distinctive black overcoats to distinguish the monks from ordinary people and from other members of the congregation (Flavigny 2017: 21).

Gerard's immediate successor, Raymond of Puy, believed that the task of the fraternity should also protect the pilgrims on all the routes that led to Jerusalem. Despite their new duties, the monks were faithful to the original charitable causes (Lange 1994: 16).

During the second crusade, numerous assignments for the Hospitallers in Central Europe were made by various personalities, testifying to the efforts of the Order's authorities to acquire facilities at the ends of the Christian world (Starnawska 1999: 25).

\section{Sovereign Military Order of Malta in Poland}

The oldest headquarters of the Sovereign Military Order of Malta in Poland was a house in Zagość in Little Poland. Henryk Sandomierski's legal act does not give 
dates, and therefore there are many hypotheses around the date of bringing the hospital to Zagość (Heś 2007: 58). The most probable theory is that in the year 1154, when the prince who had participated in the Jerusalem Crusade promised to transfer the goods to the hospital, appearance of which in Poland from the Bohemia and Moravian territories is determined before 1165/1166. The testament to the character of Henry's diploma supports this hypothesis (Smoliński 2008: 27-28). The prince gave the monks additional privileges in Czechów, Małogoszcz and Kije. At the end of the legal act he requested his brothers and their descendants not to stop their donations after his death, and to release the monks from tribute to the prince. In addition to this, permissions were given for the legal act of permanent residence and a temple (Wrzesiński 2007: 13). The hospital in Zagość already existed, probably together with the abbey, unlike the old monastery as it was founded later in the third or fourth quarter of the $12^{\text {th }}$ century, as evidenced by the source dating associated with the preserved architectural detail (Świechowski 2009: 669).

Romanesque church of St. John the Baptist was significantly rebuilt during the Gothic period, when the east wall of the presbytery and the western wall of the aisle were demolished. Internal dimensions of the endowment are: aisle $-6,76 \times 8,28 \mathrm{~m}$, presbytery $-3,40 \times 5,30 \mathrm{~m}$. Partition of the exterior walls and windows of the chancel from the original structure has been preserved (Świechowski 2009: 668-669). The side walls of the Romanesque presbytery are preserved as a whole, while the lateral walls of the aisle are preserved to the height that most probably corresponds to the level of the base of the windows' arches. Only the wall of the western façade and the wall of the presbytery closure survived in fragments, and were discovered by archaeological excavations (Dąbrowska, Tomaszewski 1964: 288). The church is an oriented building (Figure 1), and originally had its own western tower (Herrmann, Winterfeld 2015: 93). The chancel was closed and there were sacristies on both sides. The western wall of the Romanesque nave was broken down, as the church was expanded into this direction. The extension of the nave is connected with an entrance in the southern part and with the chapel of St. Isidore in the northern part. At a depth of about $70 \mathrm{~cm}$ from the current level, there are fragments of the Romanesque floor in situ, which consisted of large, rectangular limestone slabs. The floor slabs were laid on pink mortar with lime of white limestone. The interior of the aisle was illuminated with 6 window openings, which were doublesided and arranged symmetrically in three side walls. In the chancel there were two opposite windows, also jamb closed with a full arch. There is an entrance portal along southern wall closed with a full arch (Dąbrowska, Tomaszewski 1964: 287, 289). The original nave was covered with a flat wooden ceiling and the chancel carries traces of a groined vault. The external façades in the original form had rich division in the form of corner lesenes with lace decoration in the corners and two stories divided by a profiled cordon in the nave and the step of the window in the presbytery. In the nave part, the lower floor had a profiled pedestal and the upper part of the windows, three on each side in the fields and separated by half-columns, which supported the arcade frieze (Świechowski 2009: 669). Outside the nave northern wall, there was a limestone block with the image of the church in Zagość (now located in Wiślica). On another stone on the northern side of the aisle, the chancel was carved with a representation of a dragon that should prob- 


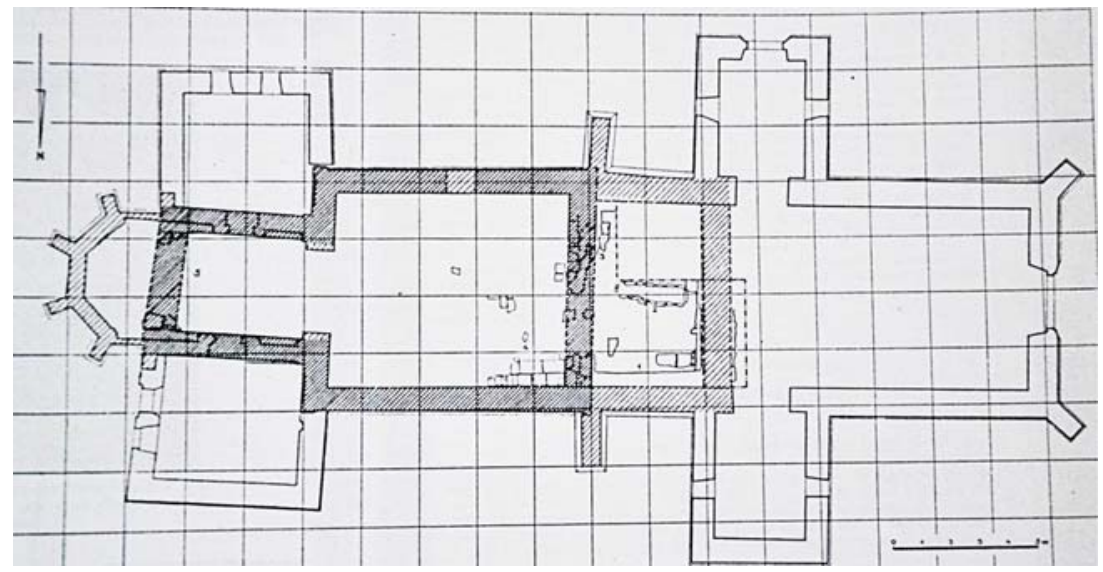

Source: Dąbwoska, Tomaszewski (1969: 289)

ably have had a magical function to protect the temple against the access of evil powers. Also, on the north side of the chancel wall, there was a shield filled with an illegible drawing (Mroczko 1988: 103). The richness of the decor of the façade does not exist elsewhere within Poland, both in terms of the two-story division, the division of the façade with half-columns, and the arcade frieze enriched with basreliefs (Dąbrowska, Tomaszewski 1964: 296). The preserved Romanesque details seem to suggest Lombard influences, assuming that the architect was a Hospitaller, or brought his kinsman (Lange 1994: 60). The sacred building was made of limestone crushes, probably from the quarries of Welcz located about $7 \mathrm{~km}$ away. The walls were complemented with architectural elements carefully. Limestone occurs from the height of $10-50 \mathrm{~cm}$. The length varies, sometimes reaching over $70 \mathrm{~cm}$ (Dąbrowska, Tomaszewski 1964: 292).

Headquarters in Zagość existed until 1321, when its goods were transferred to the Wrocław bishopric as compensation for the church process (Starnawska 1999: 27).

In Silesia, the first foundations for Hospitallers appear from the 1180s to the early $13^{\text {th }}$ century. Their origins are linked to the 12 th century-crusade and the great popularity of the cross among the clergy and the influential landowners (Heś 2007: 60).

The main centers for the Silesian Hospitallers are two houses located in the Bohemia - Kłodzko and Moravia - Grobniki (Starnawska 1999: 38).

Bringing the monks to Tyniec nad Ślęża (german: Gross-Tinz an der Lohe) is associated with preparations for the Third Crusade, in which the Bohemian and Polish crusaders were to participate (Wrzesiński 2007: 25). The surviving documents of the Bishop of Wroclaw, Żyrosław II, give the St. John's monks a new outpost. It was a church in Tyniec with tithing from Tyniec, Piława, Gosławice, Młodoszowice and Glinica (Stelmach 2000: 124). 
Figure 2: Plan of the church in Tyniec nad Ślęża

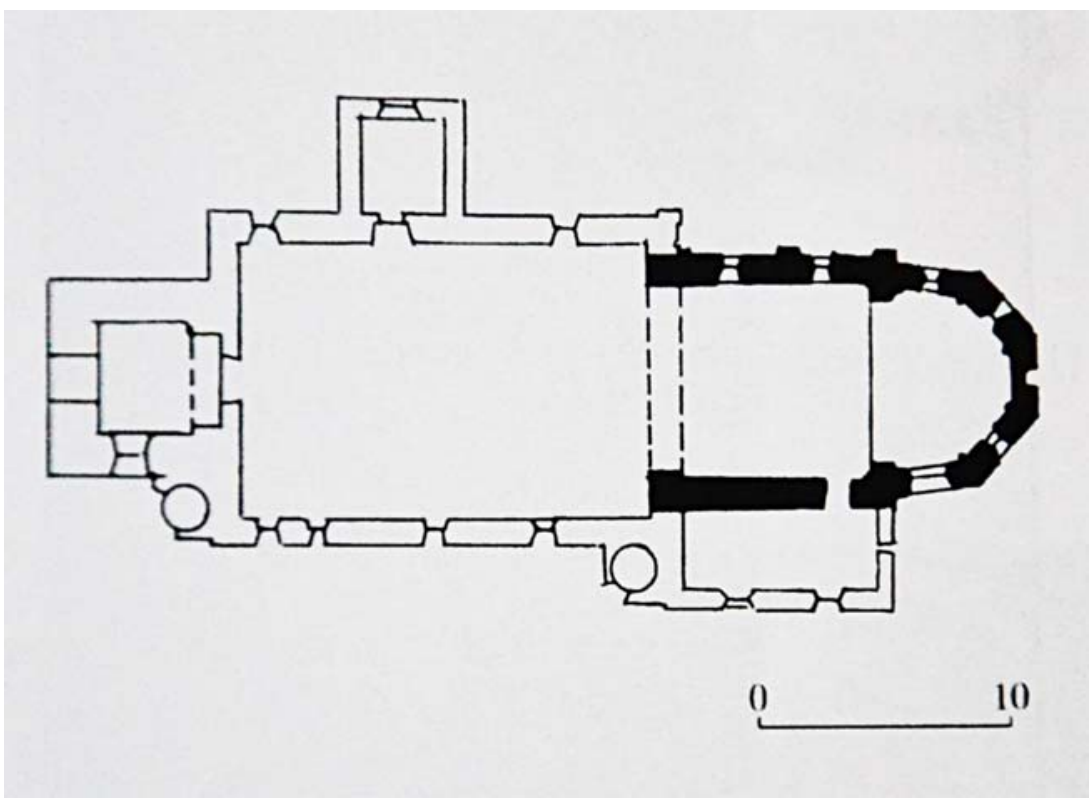

Source: Świechowski (2009: 585)

Temple of the Invocation of St. Archangel Michael was built as an oriented building (Figure 2), made of broken stone (nave) and brick (presbytery). It was a one-nave building with a separated chancel closed with a pentagonal. Internal dimensions of the endowment are: presbytery $-8.40 \times 8.20 \mathrm{~m}$ with the length of the apse reaching $4.70 \mathrm{~m}$, and the nave $-11.70 \times 17.35 \mathrm{~m}$. The building is not homogeneous, as evidenced by the materials used. In the eastern corners of the aisle, there are fragments of shafts still preserved. The chancel was built with bricks of $21 \times 13 \times 8.5-9 \mathrm{~cm}$ dimensions. The unpreserved vaulting above the chancel was supported on the cup-shaped shafts by a palmetto ornament and a plant-based motive a form that is characteristic of the second quarter of the $12^{\text {th }}$ century. Based on the proceeding curation of the Romanesque relics of the church of the Hospitallers, this part of the church is dated to the end of the $12^{\text {th }}$ century (Świechowski 2009: 585-587). The properties of Tyniec were confiscated by the Prussian authorities at the beginning of the $19^{\text {th }}$ century (Heś 2007: 64).

Ever since its formation from the Order of territorial divisions, Silesia has been part of the "language sphere" of Germany, which spread throughout Central and Eastern Europe, from Scandinavia to the Balkans. It was only natural that such a large area would be divided into smaller administrative units that would correspond to the existing regions (Lange 1994: 65).

Therefore the headquarters in Złotoryja is considered the oldest municipal endowment. The first information confirming the presence of the Hospitallers comes 
from 1267, when the pope Clement IV ordered an investigation into a complaint made by the monks against prince Boleslaw accused of breaching the income agreement (Wrzesiński 2007: 28). The patronage was granted to the Hospitallers by Boleslaw in the years 1242-1267 (Heś 2007: 72). It is known that by then the monks had already been in the city, however, it is not known to what extent they participated in the construction of the church (Lange 1994: 71).

The parish church in Złotoryja under invocation of The Blessed Virgin Mary (Figure 3) is an oriented building, brick-made of sandstone (southern transept) and bricks (chancel and the northern arm of the transept), having three naves with a transept and a separate chancel, which was originally closed with an apse. Internal dimensions of the endowment are: presbytery $-9.10 \times 9.25 \mathrm{~m}$, with the apse ray of transept reaching $2.40 \mathrm{~m}$ (Świechowski 2009: 679). The original building was designed as a three-nave basilica with a transept, presbytery and three apses from the east. The eastern part was completed with the transept and the pillars of the crossing, and the intention was to elevate the basilica to substitute for existing low arches which connect transept arms to lateral aisles (Kozaczewska-Golasz 1986: 28). The Late-Romanesque phase erected cruciform pillars with massive halfcolumns, which support the transverse arches and shafts corresponding to the diagonal ribs. The bases of the deep-cut are decorated with corner frogs in the shape of stylized leaves. The way of shaping the bases resembles the western part of the Cistercian church in Trzebnica (although it should be emphasized that they are not identical). From the original building, a round window with a secondary builtin ornamentation has been preserved in the northern wall (Jarzewicz 2014: 292). Romanesque origin is revealed by preserved portals in the transept. The southern portal is currently compatible, with free-standing, semi-circular columns. The tympanum is smooth. Originally, the portal was probably a projection; the extended part was broken off during the veneering. The traces of this manipulation are straight-cut profiles and protruding fragments in the base part. The second, northern, portal is a risalite with free-standing columns, with an entrance completed with equilateral arch. The columns were made of the same type of stone or filled with small fragments. Bases with plinths are almost identical to those in the southern portal. The main differences between the portals are in the capitals and the archivolts (Kozaczewska-Golasz, Kozaczewski 2009: 207). The forms of the portals at the southern peak are strictly Romanesque; those in the northern part are early Gothic, which indicates the time of construction of the eastern side of the church in 1212-1241 (Świechowski 2009: 684). Conservative base and headstone stonemason, especially the portals, shows the involvement of a specialized workshop, influence of which can be observed in other constructions from the immediate vicinity of Kaczawa (Świechowski 1990: 43). In 1810, as part of the secularization of religious property in Prussia, all the goods of the Order became state property. That was the end of the Maltese headquarters in Złotoryja (Lange 1994: 69).

Another church that was under the patronage of the Hospitallers was the church of The Blessed Virgin Mary in Lwówek Śląski. It was given to Prince Bernard Lwówecki in 1281 (Heś 2007: 75). The building was funded by Henryk Brodaty. In this case, Hospitallers had lived there before (Lange 1994: 71). 


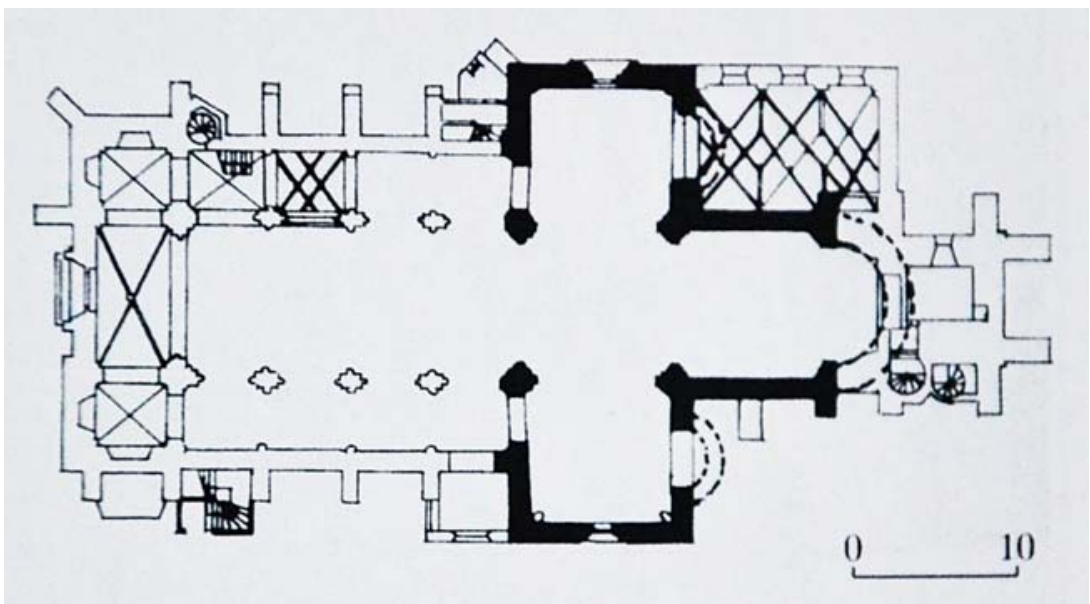

Source: Świechowski (2009: 679)

Out of the original building - probably a three-nave basilica - a two-storey western façade remained. It is characterized by uniformity of the edifice in the lower part, in which the lesenes and compose square prisms in the floor plan of the towers, passing to the octagon shape in higher levels. The division of the composition is typically Romanesque (Świechowski 2009: 289). In the preserved part, there are two portals - one on the western façade and the other at the entrance to the musical choir. The western portal seems to be largely variegated as it is made of yellow and pink sandstone. The portal in the western façade is an avant-corpse with an octagonal curve and a tympanum. The lower part of the jambs with the bases is below ground level. The portal leading from the choir to the tower is supplemented with one pair of columns with a pointed curve. The entrance was closed with a three-lined curve. Bases and lower parts of the columns were destroyed (Kozaczewska-Golasz, Kozaczewski 2009:152, 154). The corps de logis of the original building was demolished at the time of construction of the late Gothic temple. As indicated by the development of the corners on the eastern side, the corps was slightly narrower than the façade. The main changes were to wall up the rosette in the center of the façade, which was occupied by Gothic gable of portal, and replaced by late gothic windows. Preserved architectural details (profiles of cornices, window frames or portals of porches) allow to date the object in Lwówek Śląski to about 1260-1270 (Świechowski 2009: 291). Being an example of the façade of a parish church, the same Saxon models represented an attractive form for Silesia in the first half of the $13^{\text {th }}$ century (Świechowski 1990: 34).

Headquarters in Lwówek Śląski remained until the beginning of the $19^{\text {th }}$ century, when the monastery was taken over by Prussia (Starnawska 1999: 49).

The next sacral building was located in the town of Brzeg. Patronage over the parish church was received by the Hospitallers in 1280 from Prince Henryk IV 


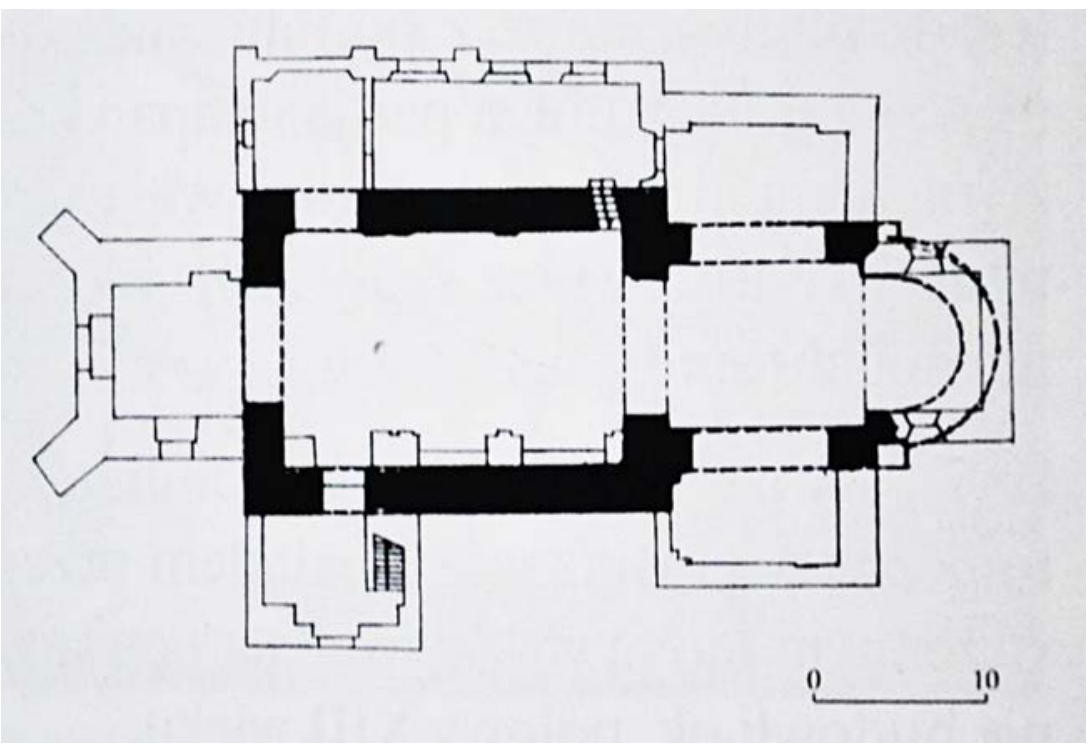

Source: Świechowski (2009: 48)

Probus. The proximity of Brzeg and Eosiowo allows us to assume that the initiative of obtaining this temple came from the elite of monks from Łosiowo (Starnawska 1999: 42).

The Romanesque church endowment of the God's Corp in Brzeg was an oriented (Figure 4) one-nave building using the Slavic bricklaying system with a separate presbytery closed by the original apse. Only the walls of the aisle remained from the original building in full height, partly presbytery, while the apse was distinguished during the archaeological research. The temple's structure was destroyed by the construction of a Gothic tower and interior was completely revamped in the baroque style. The gable wall between the nave and the chancel is preserved in the attic, while the nave wall itself remained visible in a fragment of the arcade frieze (Świechowski 2009: 49).

It is estimated that the Hospitallers founded about 30 churches in Silesia. The focus on pastoral activity was characteristic for the Silesian region, and caused more and more "burghers" to manage the goods of the Order, example of which could have been seen in Brzeg (Lange 1994: 64, 70). The first monastic endowment in Silesia was influenced by the Bohemian and Moravian neighborhood (already heavily occupied by the Maltese Order), the interest of the Hospitallers by the Bishop of Wrocław - Żyrosław, and local knights. At the turn of the $12 \mathrm{th}$ and $13^{\text {th }}$ centuries, religion entered the way to create a separate administrative unit of the Order. In 1205, it was subordinated to the Silesian master Robert (Smoliński 2008, 129). In Silesia, the monks did not develop characteristic type of two-storey 
Figure 5: Plan of the church in Poznań

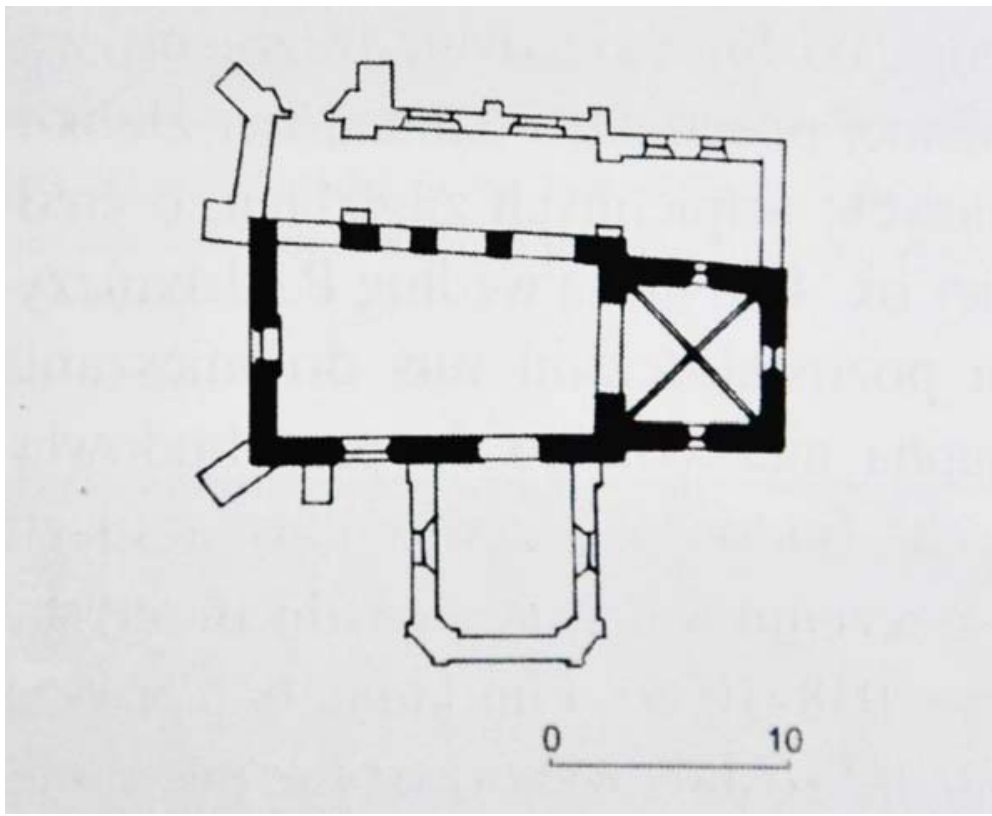

Source: Świechowski (2009: 382)

chapels; they served religious purposes only (lower level) and as a hospital (upper level). At least until the $15^{\text {th }}$ century, headquarters had their own internal infirmary (Heś 2007: 342, 344). Therefore, it was then that the Maltese Order, in agreement with the councilors, prepared a regulation that defined who and in what conditions would be staying in a hospital-hospice. A small number of hospitals (e.g. Poznań, Wrocław, Złotoryja, Zagość) related to the number John Baptist's monks, was rather moderately involved into this activity (Wrzesiński 2007: 43-44).

Outside of Silesia, Hospitallers also received goods in Great Poland. For the hospital-hospice activity for the poor and wanderers, the monks received tithes from seventeen villages (Lange 1994: 100). Mieszko Stary invited the Hospitallers to Poznań, and in 1187, he gave them the hospital of St. Michael (founded by the Bishop of Radwan in 1170), located outside the area of the then development (Starnawska 1999: 36). The origins of the Poznań Hospitallers are not known. Most likely, they arrived from Moravia or Bohemia, possibly from the already mentioned convent in Zagość. It is certain, however, that the authorities of the headquarters had resided in Prague (Lange 1994: 102).

Parish church of St. John of Jerusalem Behind the Walls, formerly St. Michael in Poznań (Figure 5) is an oriented building, brick-built in the venetian system: one nave with a separate chancel that was closed straight. Internal dimensions of the endowment are: presbytery $-5.90 \times 5.90 \mathrm{~m}$, nave $-7.80-8.30 \times 13.30 \mathrm{~m}$. The spatial 
layout of the interior and the masonry itself have undergone significant changes due to numerous alterations. From the original building period, brick groined vaults with ribs in the chancel survived together with partly walled nave and a recessed oculus in the western façade. In the nave originally covered by a beam ceiling, a star-vaulting was built and the building was buttressed. On the right side of the western portal, a capital letter was placed with a floral motif, however, on the left, was a base of column used instead. Type of spatial layout combined with details of construction technique (brick dimension $30 \times 13.5-14.5-15 \times 7-8 \mathrm{~cm}$ ) indicates the time of the construction of the building; around the middle of the $13^{\text {th }}$ century (Świechowski 2009: 382-384). At least from the middle of the $14^{\text {th }}$ century, the church of John of Jerusalem (Baptist) served as a parish church. This premises was secularized by the Prussian government in 1832, after the death of the last Knight Commander Andrzej Marcin Miaskowski (Koszutski 2013: 12). What distinguishes the Poznań headquarters from the previously mentioned is its operating time, over 600 years (Lange 1994: 101), (after the cassation of Hospitallers who returned to Poznań in the early 1990s).

The churches mentioned above had originally belonged to the Order of Hospitallers (Figure 6). Thanks to preserved sources, written and partially verified, we are able to determine their development in Romanesque style and to trace the history of the headquarters which they were subjected to. In addition to the above mentioned areas, monks also had estates in Pomerania and Kujawy (the temples were built in Gothic style).

\section{Poor Fellow-Soldiers of Christ and of the Temple of Solomon in POLAND}

As a result of the dissolution of the Templar Order in 1312, the offertory donated under the auspices of the Hospitallers came to the next temples. Their number is similar to that in the earlier part of the paper (Table 1).

Table 1. Hospitaller's romanesque churches

\begin{tabular}{llll}
\hline Place & Dating & Invocation & Affilation \\
\hline Brzeg & 1st half XIII c. & Corpus Christi & Silesia \\
\hline Lwówek Śląski & about 1260-1270 & Blessed Virgin Mary & Silesia \\
\hline Poznań & half XII c. & $\begin{array}{l}\text { St. Michael Archangel; } \\
\text { now: John of Jerusalem }\end{array}$ & Great Poland \\
\hline Tyniec nad Ślężą & 2nd quarter XIII c. & St. Michael & Silesia \\
\hline Zagość & 3/4th quarter XII c. & John the Baptist & Little Poland \\
\hline Złotoryja & $1212-1224$ & Blessed Virgin Mary & Silesia \\
\hline
\end{tabular}

All the changes Hospitaller's commanders made that occurred during the Middle Ages, especially after the disposal of the Knights Templar, were a good example of the attempt by the Order to adapt to the political situation after the crusades (Starnawska 1992: 3).

The Templars came to Poland in the third decade of the $13^{\text {th }}$ century. This was due to the policy of the Order, which began to take care of its acquisition of goods 
in Europe. They were brought back to the Polish territories thanks to simultaneous endowment: Henryk Brodaty (Leśnica), Władysław Odonic (tithes) and Barnim I (Banie). The simultaneous action of three rival princes indicates the inspiration of the Order, which wished to expand its estates at any cost (Starnawska 1999: 55). The lands that were given to the Templars were located in the March of Brandenburg, Mecklenburg and neighboring parts of Pomerania. After some time, an administrative unit called the Brandenburgian Baleat was established (Lange 1994: 90).

After the loss of the Holy Land by Christians, the meaning of the existence of the Templars or the Hospitallers in the after-Crusade period was questioned. It is well-known FACT that the Order of the Knights of Christ did not survive the crisis, and its knightly character made it difficult to adapt to the new role (Starnawska 1992: 3). Much of the area that belonged to the Order of the Knights of the Temple had been originally uninhabited. At the time of their dissolution in 1312, the Templars possessed goods with strong centers in Leśnica, Chwarszczany, Sulęcin, Wielka Wieś, Czaplinka and Rurka. All these "houses" and estates, according to the bull of Pope Clement V, passed into the hands of the Order of St. John (Lange 1994: 91) (Table 2).

Table 2: Churches aquired from Knights Templar

\begin{tabular}{llll}
\hline Place & Dating & Invocation & Affilation \\
\hline Banie & half XIII c. & $\begin{array}{l}\text { St, Mary Magdalene; } \\
\text { now: Our Lady of } \\
\text { Support of the Faithful }\end{array}$ & Pomerania \\
\hline Eagów & about half XIII c. & $\begin{array}{l}\text { originally unknown; } \\
\text { now: St. Antoni from } \\
\text { Padua }\end{array}$ & Silesia \\
\hline Rurka & after 1234 & unknown & Pomerania \\
\hline Swobnica & after 1234 & $\begin{array}{l}\text { Originally unknown; } \\
\text { now St. Casimir }\end{array}$ & Pomerania \\
\hline
\end{tabular}

\section{Romanesque churches aquiRed fROM KNIGHTS Templar}

One of the settlements which was part of the Hospitallers' goods was the town of Banie (Figure 6). Here IS the Church of Mary Magdalene, and, in the moment of changing the "owner", the Church of Our Lady of Support of Faith. The temple is one of the most monumental endowments made solely by the use of overhead erratic ias a building block. The church remained almost intact until the 19th century (Świechowski 1990: 171). The temple is an oriented, three-nave, three-spanned pseudo-basilica with a separate straight-closed presbytery. Internal dimensions of the endowment are: presbytery $-9.90 \times 15 \mathrm{~m}$, nave $-18.50 \times 17.35 \mathrm{~m}$; wall thickness - $1.35 \mathrm{~m}$ (east chancel), $2.85 \mathrm{~m}$ (western nave). To the almost square corpus, four pillars were introduced. The interlaced arcades and rainbow arches originate the original building. The presbytery with the main nave was covered by a beam ceiling. From the original opening a part of the entrance on the southern aisle the eastern side, partly through the entrance opening, which leads to the former sac- 


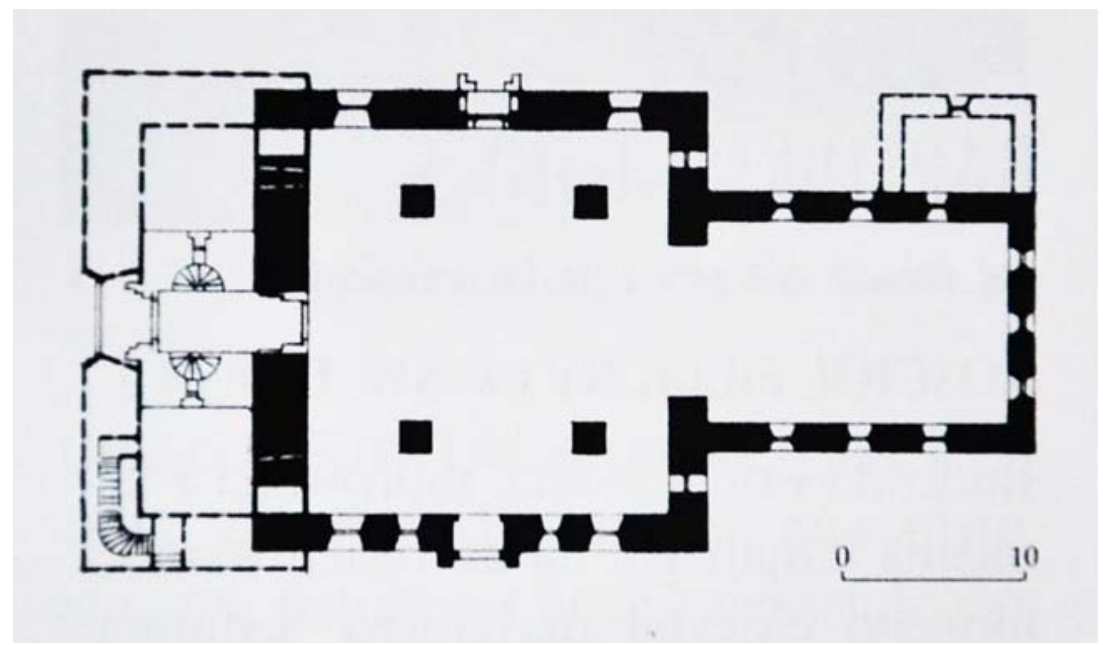

Source: Świechowski (2009: 43)

risty (Świechowski 2009: 43-44). The presbytery is of a small size and ends with an apse, a rectangular choir illuminated by three windows related to the monastery architecture (Świechowski 1990: 44).

Another church among the estates of St. John's monks was the temple of St. Antoni from Padua (the original name is not known) in Łagów. It is a one-nave building with a separate chancel closed with a semi-circular apse (Figure 7). Internal dimensions of the endowment are: ray of apse $-2.10 \mathrm{~m}$, presbytery $-6.55 \times 5.50 \mathrm{~m}$, nave $-10.35 \times 6.90 \mathrm{~m}$. The apse is vaulted and the presbytery was covered by a wooden ceiling. The church was built of quarry stone, and maintained its spatial layout (Kozaczewski 1994: 22); however, all windows and entrance openings have been transformed (Świechowski 2009: 292). The temple's building survey has revealed that it has essentially two phases of construction, which fall into the high and late Middle Ages. The outer eastern wall of the chancel suggested the existence of a fragment of an earlier building, adapted for the construction of the later Gothic church (Michno 1969, 351). The Łagów temple met the religious needs of the inhabitants of the bailey and the village, as mentioned in the inventory book, and fulfilled parish functions for the nearest neighborhood of Łagów (Przybył 2006: 403) To Hospitallers from Łagów also owned land previously belonging to Templars from in Wielowie, Boryszyn, Templewo, Żarzyn or today nonexistent Cemelno (Wasilkiewicz 2016: 196-197).

The village of Rurka, situated in Pomerania, was another village that fell into the hands of the Hospitallers. There is a preserved chapel raised by the Templars with its original name being unknown until today.

The former chapel of the Knights of Christ is an oriented building (Figure 8 ), made of granite slabs, having one nave with a separate straight-closed pres- 
Figure 7: Plan of the church in Eagów

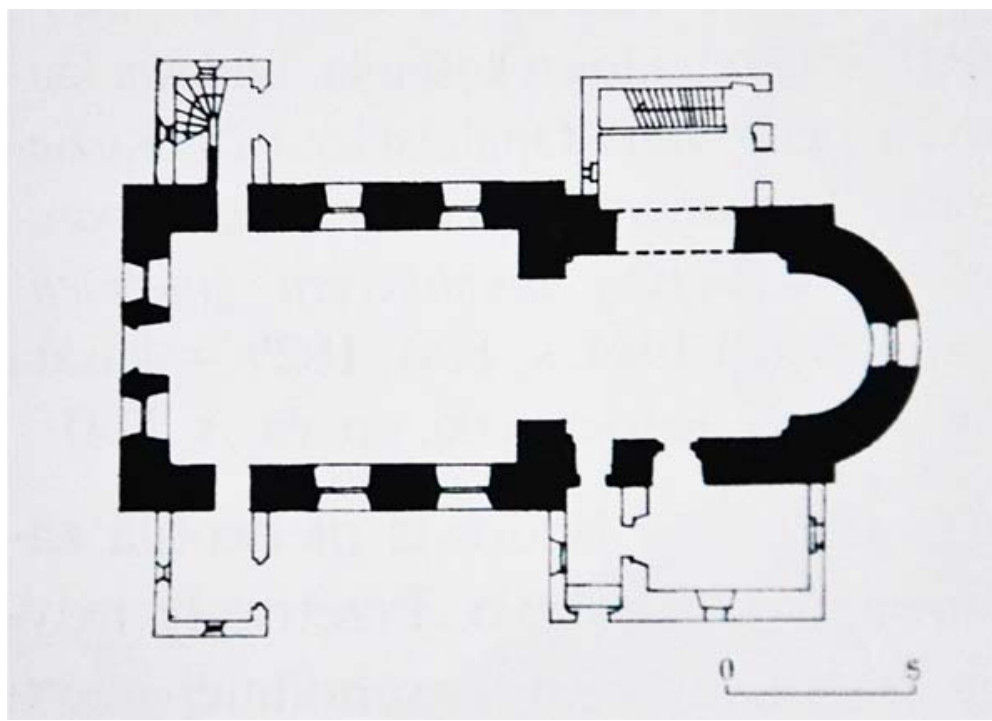

Source: Świechowski (2009: 292)

bytery. Internal dimensions of the foundation are: presbytery $-5.04 \times 6.25 \mathrm{~m}$, nave $-5.04 \times 6.25 \mathrm{~m}$, wall thickness $-1 \mathrm{~m}$ (presbytery), $1.15 \mathrm{~m}$ (nave; Świechowski 2009: 401). What distinguishes the chapel in Rurka from its modern buildings is the unique, extremely accurate way of turning granite cubes that make up the original face of the outer walls. Despite the numerous chapel's transformations, the temple retained the best visible mass of the early priests of the Templar monks in Eastern Europe. Its ground plan refers to the simplest religious buildings of this type. The walls were built with the technique of opus emplectum. The center of the wall was filled with broken stones, granite shells, and covered by lime-sand mortar. There are small boulders built in within the outer face of the wall (Kołosowki 2009: 547548). The original semicircular windows were preserved in the presbytery and the northern wall of the nave. The walled-up jamb of the circular window is preserved in the western peak wall and the semi-circular portal in the northern wall of the aisle. Above the current ceiling in the presbytery there are prominent brackets of the arched ceiling's corbels, probably forming a sacral vault (Świechowski 2009: 402).

The interior of the former temple of the monastery exposes the scale of the destruction that has taken place since the end of the $19^{\text {th }}$ century, replacing the granite parts for brick walls. The nave from the east choir was separated by a chancel arch. This fragment is preserved within the south wall. During the archaeological survey, the foundation stone was found, the wall cropping of which formed a layer of flat, broken stones which were laid on limestone. Underneath the stone, there were granite boulders freely laid on a narrow space beneath the foundation. 


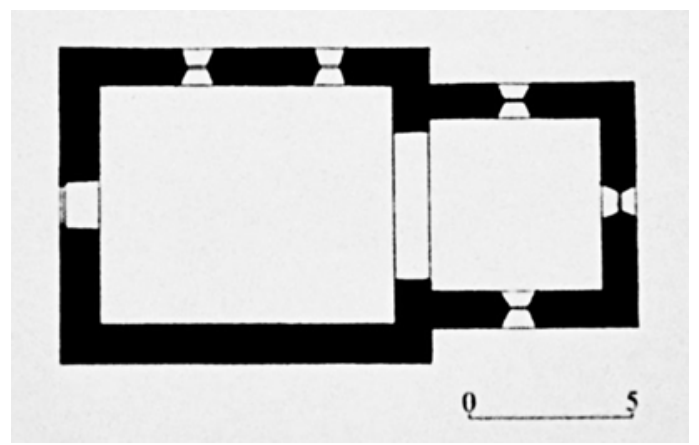

Source: Świechowski (2009: 401)

In the interior, the relics of the altar have been exposed, and lowering the area has revealed the medieval utility level of the foundation (Kołosowski 2009: 549, $552-553)$.

The last Romanesque church that belonged to the Knights Templar, and has been preserved to this day is the temple of St. Casmir in Swobnica (its original name is unknown). The relics of the oriented building are made of eroded boulders laid in regular layers of an average height of $25-30 \mathrm{~cm}$, and the church is constructed with a single nave without separated presbytery. Reconstruction from the nineteenth century effaced the original character of the building, among other things, by removing the window openings or flattening the façade of the walls. From the original stonework, portals have been preserved (now walled up). In the southern wall is an original jamb - probably the entrance for the priests - next to the western is half jamb, the analogically made, like in the north wall (Świechowski 2009: 512-513).

\section{Conclusions}

The position of the Hospitallers in the Brandenburg district was very strong, but at the end of the $15^{\text {th }}$ century they became more dependent on the Hohenzollerns (Wasilkiewicz 2016: 222). By the takeover of the Templars, the position of the Hospitallers increased, and the character of the headquarters was changed. While the local town councils were dominated by the Knights, the Templars had formed their headquarters in the country. This tendency also began to adjust to the older seat of the monks of St. John. As a result of these processes, two concentrations of headquarters were created: the Silesian prefects dominated the city, while in the Brandenburg area there were more country houses (Starnawska 1999: 71). In the first half of the $13^{\text {th }}$ century the headquarters in Great Poland, Silesia and Pomerania were connected with the Hospitallers in Moravia administratively. The Maltese Order from Poland and Pomerania was indirectly under Praga (Smoliński 2008: 300). In the area of the United Kingdom of Poland, after the disposal of the 
Figure 9: Hospitaller's romanesque churches (square points) and churches aquired from Knights Templar (round points)

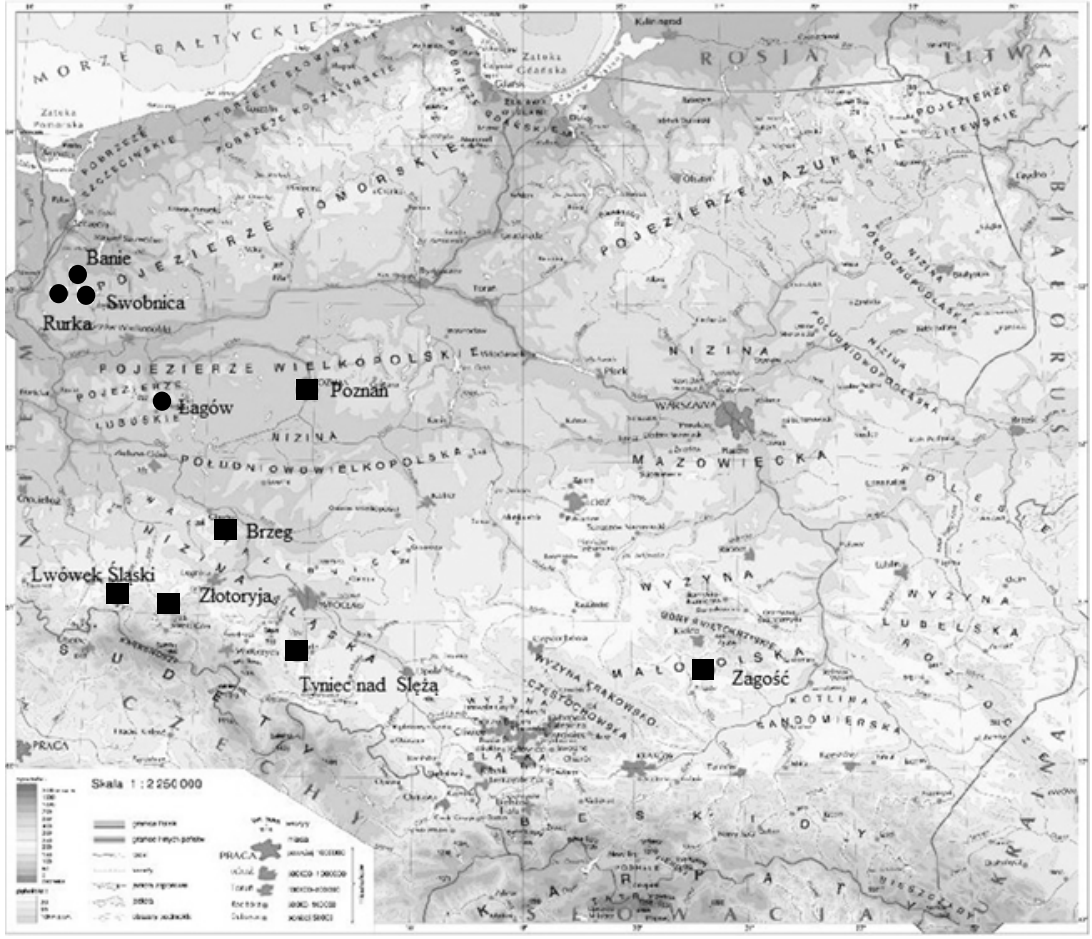

Source: Świechowski (2009: edited by the author)

house in Zagość and the Kujawy centers, only the headquarters in Poznań and Kościan remained (Starnawska 1999: 71). None of the medieval headquarters of religious orders exist in Silesia nowadays.

The beginning of the $14^{\text {th }}$ century, the monasteries of the St. John and the Templars, become one monastery experienced on the Pomeranian-Lubuskie border. Bringing the Oder and the Baltic knights of the Order was a way to join in the battle for the Holy Grave. However, the brothers quickly abandoned their original duties, trying to fight the heathen Prussians, and they administered pastoral services in urban and rural parishes. However, approaches to the development of the Hospitallers, which were weak in terms of organization and property, led to a failure in sustaining the effects of their actions (Stanawska 1992: 28).

Described Romanesque churches, which were built for the Order of St. John, or donated under patronage, and located within the present borders of Poland, are somehow the results of the crusade. Most of the remaining buildings have sacred character. Unfortunately, as a result of the Reformation (e.g. Kłodzko, Łagów), warfare (e.g. Chwarszczany, Wrocław), secularization (e.g. Oleśnica Mała, Koźle, 
Leśnica), changes of headquarters (e.g. Głubczyce, Solec), takeover by another Order (e.g. Pilawa, Cieplice), random accidents (e.g. Słońsk) or changing the location of the church (e.g. Strzegom), it is not always possible to recognize certain features by full archaeological and architectural research is not always possible. Also disputes among researchers regarding the dating of documents giving specific facts (which are not always possible to trace) makes it difficult to thoroughly analyze the history of assumptions. In spite of its rich source database (e.g. Kodeks Dyplomatyczny Wielkopolski, Schlesische Urkundenbuch, Codex Diplomaticus Silesiae) which allows to verify donations, endowments or patronage laws and enter the boundaries of the activities of the Hospitallers in certain areas, the lack of extensive, interdisciplinary research does not allow full identification of all churches, although historical references may suggest the Romanesque origin of the temples. The map (Figure 9) of the Romanesque churches shows the location of the premises (in addition to Zagość in Little Poland), concentrated in the southwestern part of Silesia (after the acquisition of the Templars, the focus moved to the borderland of Brandenburg), which enabled the Order better connection to the Bohemia and Moravian territories (and subsequently also to the German territories), so they were not far from the centers of power of the Order.

Donations to the monks of St. John created a sort of "grid" of relationships between the villages/lakes/forests and other economic features, so that a particular house, church or a hospital was provided for its own business, but this greatly influenced the size of the convent. The profits from their possessions, especially surplus, went to the Holy Land in order to maintain their hospitals and fight the Muslims.

Hospitallers received most of the existing parish temples and centers that provided care for the sick and the poor. When there was no support, they were able to make the promoter build a church, and then to transfer it to the Order. The existing facilities were adapted to new needs; the decisions made were made carefully from the point of view of the existence of a hospital or temple in the space of a city and a village (especially in the context of religious orders, which often involved the creation of a new headquarters). The churches themselves, like other religious communities, came from knightly, bourgeois or princely endowment.

The Romanesque churches which were in the hands of the monks are characterized by a simple, uncomplicated plan. By analyzing the temples built in the countryside, one can observe that they have no gallery, western massif or chapel (Brzeg, Tyniec, Zagość). The shape itself does not differ from the concept of small Romanesque endowments built in that period in Polish lands, and the building material used was the one used in the region. Except from Zagośc, where the external wall division is a feature specific for the church, making it different from other temples, the other churches in villages are typical for their simplicity in the solution of the exterior façade. The construction technique does not stand out from other Romanesque religious buildings of similar traits, and used both stone and brick cuts. Also, the scale of these temples is small. However, enriched architectural solutions can be seen in the masses of urban churches, which, due to their location, had to be characterized by greater "capacity" of the faithful (Złotoryja, Lwówek Śląski). The construction of a building to fulfill its basic functions was also 
dictated by the Order's patronage (the council was administered by a city council), and ownership of a particular church. Also, the churches and chapels which the Knights took over after the Templars do not diverge too much from the building solutions used in the aforementioned places. Of course, they have the characteristic conception of the architecture of the Order of the Knights of Christ (Rurka), but the concept itself does not exhibit too complicated or innovative architectural solutions. These places, in addition to the strict sacred functions, served as hospitals thanks to which the monks were able to take care of their patients.

However, we are not able to indicate the changes that the Hospitallers made, after the acquisition of the Templars, as accurately as possible within all the churches. We can rely on incomplete information based on sources, but thorough field verification is required within interdisciplinary research, which would cover fields such as archeology, architecture, history or art history. Only then there will be an opportunity to change, or to confirm unequivocally all the facts, and above essentially, to trace the development of the purpose and the history of the particular temple.

\section{BIBLIOGRAPHY}

Dąbrowska, E., A. Tomaszewski. 1964. "Badania prowadzone w 1962 roku w obrębie kościoła parafialnego w Zagości, pow. Pińczów." Pp 286-304 in Sprawozdania Archeologiczne, vol. XVI. Warszawa: Instytut Archeologii i Etnologii Polskiej Akademii Nauk.

Dąbrowska, E., A. Tomaszewski. 1969. "Badania w roku 1963 w obrębie kościoła parafialnego w Zagości, pow. Pińczów." Pp 287-291 in Sprawozdania Archeologiczne, vol. XX. Warszawa: Instytut Archeologii i Etnologii Polskiej Akademii Nauk.

Flavigny, B. 2017. Joannici. Historia Zakonu Maltańskiego. Kraków: Wydawnictwo Astra. Herrmann, Ch., D. von Winterfeld. 2015. Mittelalterliche Architektur in Polen: Romanische und gotische Baukunst zwischen Oder und Weichsel, vol. I. Petersberg: Michael Imhof Verlag $\mathrm{GmbH} \& \mathrm{Co}$.

Heś, R. 2007. Joannici na Ślasku w średniowieczu. Kraków: Avalon.

Jazrewicz, J. 2014. Kościoly romańskie w Polsce. Kraków: Wydawnictwo M.

Kołosowski, P. 2009. "Późnoromańska kaplica w Rurce na Pomorzu Zachodnim w świetle badań dziejów założenia zakonnego templariuszy." Pp 545-572 in T. Janiak (ed.). Architektura romańska $w$ Polsce. Nowe odkrycia i interpretacje. Gniezno: Muzeum Początków Państwa Polskiego.

Koszutski, M. 2014. Dziewięć wieków Joannitów - Kawalerów Maltańskich. Poznań: Oficyna Wydawnicza Mówią Wieki.

Kozaczewska-Golasz, H. 1986. "Miejskie kościoły parafialne pierwszej połowy XIII w. na Śląsku." Kwartalnik Architektury $i$ Urbanistyki 31 (1): 17-41.

Kozaczewska-Golasz, H., T. Kozaczewski. 2009. Portale trzynastowiecznej architektury na Ślasku. Wrocław: Oficyna Wydawnicza Politechniki Wrocławskiej.

Kozaczewski, T. 1994. "Wiejskie kościoły parafialne XIII wieku na Śląsku (miejscowości H-O)." Pp 3-244 in M. Kopeć (ed.). Prace Naukowe Instytutu Historii Architektury, Sztuki $i$ Techniki Politechniki Wroctawskiej, vol. 28, Seria Monografie 16. Wrocław: Oficyna Wydawnicza Politechniki Wrocławskiej.

Lange, T. 1994. Szpitalnicy. Joannici. Kawalerowie Maltańscy. Poznań: Wydawnictwo DRAWA. 
Michno, S. 1969. "Łagów, pow. Opatów." Pp 351-352 in Informator Archeologiczny. Badania 1968. Warszawa.

Mroczko, T. 1988. Polska sztuka przedromańska i romańska. Warszawa: Wydawnictwo Artystyczne i Filmowe.

Przybył, M. 2006. "Hus Lagow. Z dziejów komandorii joannitów w Łagowie." Pp 395-404 in A. Wyrwa (ed.). Cognitioni Gestorum - studia z dziejów średniowieczna dedykowane profesorowi Jerzemu Strzelczykowi. Poznań, Warszawa: DiG.

Smoliński, M. 2008. Joannici $w$ polityce ksiażat polskich i pomorskich od polowy XII do pierwszego ćwierćwiecza XIV wieku. Gdańsk: Wydawnictwo Uniwersytetu Gdańskiego.

Starnawska, M. 1992. "Mnisi-Rycerze-Szlachta. Templariusze i Joannici na pograniczu wielkopolsko-brandenbursko-pomorskim." Kwartalnik Historyczny 99 (1): 3-31.

Starnawska, M. 1996. "Krucjata i Ziemia Święta w duchowości zakonów krzyżowych w Polsce średniowiecznej." Pp 167-179 in J. Mandziuk (ed.). Saeculum Christianum: pismo historyczno-społeczne, vol. 3/1. Warszawa: Wydawnictwo Uniwersytetu Kardynała Stefana Wyszyńskiego w Warszawie.

Starnawska, M. 1999. Między Jerozolima a Lukowem. Zakony krzyżowe na ziemiach polskich $w$ średniowieczu. Warszawa: Wydawnictwo DIG.

Stelmach, R. 2000. "Dokumenty śląskich komend joannitów w zasobie Centralnego Archiwum Państwowego w Pradze." Pp 111-133 in S. Kuczyński (ed.). Archeion, vol. CII. Warszawa: Naczelna Dyrekcja Archiwów Państwowych.

Świechowski, Z. 1990. Sztuka romańska $w$ Polsce. Warszawa: Arkady.

Świechowski, Z. 2009. Katalog architektury romańskiej w Polsce. Warszawa: Wydawnictwo DIG.

Wasilkiewicz, K. 2016. "Templariusze i Joannici w biskupstwie lubuskim (XIII-XVIw.)." Pp 7-289 in L. Mrozewicz (ed.). Acta Humanistica Gnesnensia, vol. X. Gniezno: Wydawnictwo Naukowe CONTACT/ABC.

Wrzesiński, S. 2007. Joannici. Warszawa: Egros. 